\title{
EXTREME PRECIPITATION EVENTS IN THE MOUNTAIN AND SUB-MOUNTAIN AREAS OF THE FĂGĂRAŞ MOUNTAINS IN JUNE 10 TO 11, 2011
}

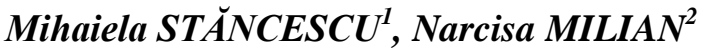

\begin{abstract}
In the last decades, permanent residencies and temporary tourist dwellings have been built in the sub-mountain area of the Făgăraş Mountains, mainly in the proximity of the Olt River, being exposed to significant floods during extreme precipitation events. The studied case started with a decade of both thermal and rainfall extreme events. Major floods occurred in the night of 10/11 June, generated by significant precipitation amounts, setting a new historical record, of $236.6 \mathrm{~mm} / 24 \mathrm{~h}$. Flood level was exceeded on 3 tributaries (Cârţişoara, Arpaşu Mare, Arpăşel), damages were reported at about 100 houses, 250 persons were evacuated, tens of ha were flooded, several bridges were destroyed. The meteorological case analysis covers the mountain and sub-mountain area, and it is based on data retrieved from meteorological stations, global models ECMWF and ARPEGE, ALADIN mesoscale model and satellite images.
\end{abstract}

Keywords: extreme precipitation, mountain, sea-level pressure, temperature

\section{INTRODUCTION}

Severe weather events have a negatively impact on economic and social life. Rainfall is the meteorological factor with most uneven distribution, due to the topographical configuration, slope and slope orientation to the air masses flow. Torrential rains theory studies using the Hellmann criteria, take account on average intensity, total rainfall amount and duration (Donciu 1929; Bogdan, 1999). Torrential rains registered over Romania depend on altitude and landform, because of the Carpathians, that act as an orographic barrier to humid air advection (Ion-Bordei E., 2009). After Hellmann, a rainfall is torrential if the average intensity is $0.2 \mathrm{~mm} / \mathrm{min}$ and excessive torrential if it is $0.45 \mathrm{~mm} / \mathrm{min}$, for 121-180 minutes. Landscape variety and local orography are very important for the quantitative and intensity precipitation distribution in Transylvania, as well as antropic influences. Important precipitations have been also registered in June 1988 (Stănescu M, 2012) and July 2009 (Blaga C, 2009).

In Transylvania, and Făgăraş Mountains area as well, first decade of June 2011 was a period of both thermal and rainfall extremes. During the first week of the month, the weather was very hot in the afternoon, with maximum temperatures higher than average by 6-7 ${ }^{\circ} \mathrm{C}$. Between June 8 to 11 , weather cooled, and was

\footnotetext{
${ }^{1}$ Doctorand la Şcoala Doctorală de Ştiinţe, Universitatea Craiova, Romania, email: stancescu_mhl@yahoo.com;

${ }^{2}$ Regional Meteorological Center Transilvania-Sud Sibiu, Romania, email: narcisa.milian@gmail.com
} 
characterized by a severe atmospheric instability, with torrential rains (on June 10: 44 mm/12-15 UTC, 34 mm/15-18 UTC, 50 mm/18-21 UTC, 49 mm/21-24 UTC National Administration of Meteorology Data base) and flooding in the submountainous Făgăraş Mountains area, during the night of June 10 to 11, significant wind intensification, transient storm-like, thunder and hail. On June 9, 2011, the recorded amounts of rain in Făgăraş Mountains area have been between $18 \mathrm{~mm}$ at Sebeş Olt and $37.2 \mathrm{~mm}$ at Porumbacu de Sus and in the mountains, at Bâlea-Lac, $32.3 \mathrm{~mm}$. Significant amounts of water, up to $46 \mathrm{~mm}$, were also recorded in Mureş, Covasna and Harghita County, up to $33 \mathrm{~mm}$ in Braşov County, and up to $35 \mathrm{~mm}$ in Alba (National Administration of Meteorology Data base).

Between June 10 to 11, the recorded amounts of water in Sibiu county were: $31.6 \mathrm{~mm}$ at Boiţa, $98.1 \mathrm{~mm}$ at Arpaş and in the mountains - $236.7 \mathrm{~mm}$ at Bâlea-Lac. In Braşov County, most of the recorded water quantities were between 25 and 45 $\mathrm{mm}$, with a maximum of $63 \mathrm{~mm}$ at Dopca. In Covasna and Mureş County, most of the registered water quantities have been between 20 and $30 \mathrm{~mm}$, but outstanding amounts in Covasna County were at Covasna $(64.8 \mathrm{~mm})$ and Lăcăuţi $(73.2 \mathrm{~mm})$ and in Mureş County at Sighişoara $(62.9 \mathrm{~mm})$ and Vânători $(61.0 \mathrm{mmp})$. Less water quantities were registered in Alba County (with a maximum of $24 \mathrm{~mm}$ ) and Harghita County (with a maximum of 39.81 /sqm at Varşag) (Fig.1). On June 11, significant rainfall quantities were recorded in the mountains, at Bâlea-Lac $(30.9 \mathrm{~mm})$ and Lăcăuţi $(29 \mathrm{~mm})$ (National Administration of Meteorology Data base).

The total amount of water recorded at Bâlea-Lac between June 8 and 12, was of $311 \mathrm{~mm}$, with the highest amount, of $236.7 \mathrm{~mm}$, recorded in 24 hours, between June 10 and 11, at 06 UTC (Fig.1).

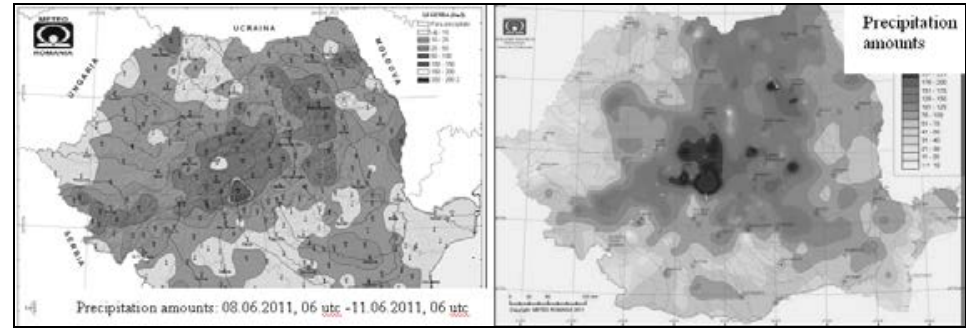

Fig. 1. The amount of rainfall within June 08-11.06.2011, 06 UTC and total monthly rainfall amount for June 2011 (National Administration of Meteorology, Archive maps)

After these heavy rainfalls, three Middle Olt river tributaries (Cârţişoara, Arpaşu Mare and Arpăşel - Fig. 2) have exceeded the flood quota, 100 houses were affected by floods, 250 people were evacuated, tens of hectares were flodded.

According to Sibiu Emergency Inspectorate report, in Sibiu County, Cârţişoara, Arpaş and Porumbacu were affected by floods, people have been evacuated from 189 houses in Cârţişoara and 62 in Arpaş. Parts of roads and several bridges were damaged, hectares of arable land and grassland were flooded and some electricity pylone felt. In other counties, the problems have been smaller, a few flooded basements in Reghin (Mureş County) and Baraolt (Covasna County) and some fallen trees over a river basin in Viştea (Braşov County). 


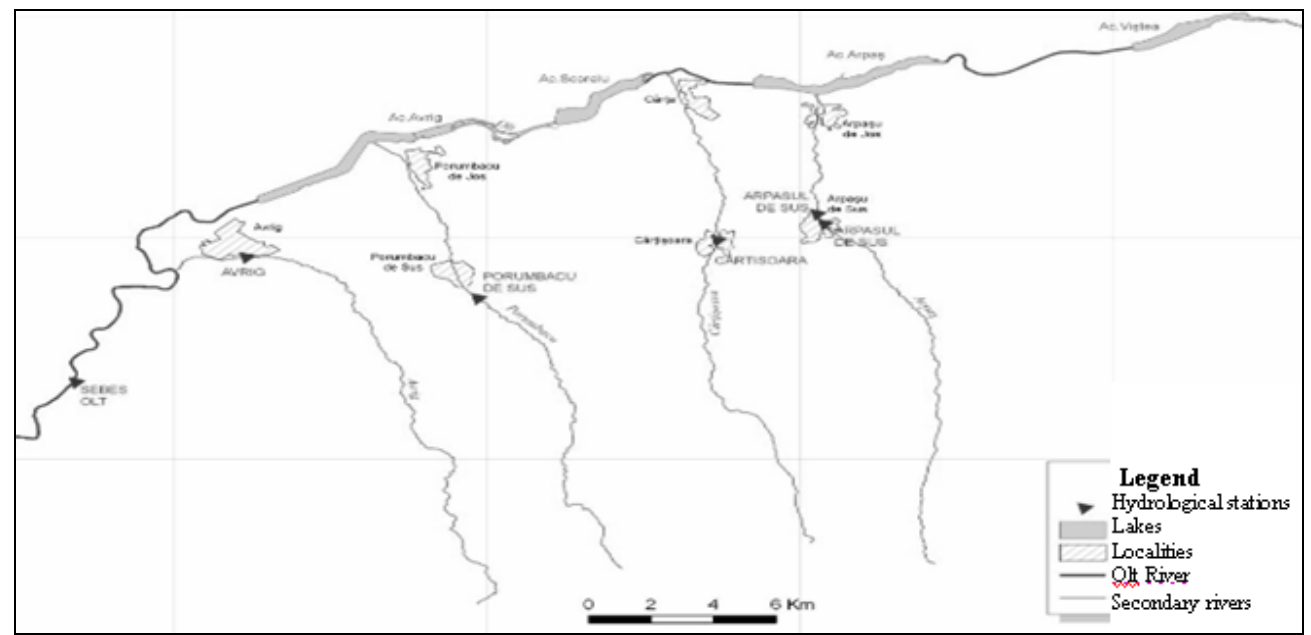

Fig. 2. Hydrographic network of middle Olt river (SGA Sibiu map)

\section{DATA AND METHODS}

In this paper, synoptic conditions between June 08 to 11, 2011 in Romania was studied. For this purpose, sea-level pressure, geopotential, temperature and humidity at $850 \mathrm{hPa}, 700 \mathrm{hPa}$ and $500 \mathrm{hPa}$ level have been reanalyzed, as well as the outputs of ARPEGE and ECMWF large scale numerical model, ALADIN mesoscale model and satellite images. In order to see the evolution and distribution of atmospheric sea-level pressure, wind average speed and direction, weather phenomenon, hourly sinoptic maps were used, with observation data received from Romanian National Meteorological Administration weather stations network. Sealevel pressure was drawn by $1 \mathrm{hPa}$.

\section{RESULTS}

\subsection{Synoptic conditions}

Between June 8 and 9 (06 UTC), over most of Europe a depressionary field was acting: the Icelandic cyclone, with a $1000 \mathrm{mb}$ core over the British Island and a $1005 \mathrm{mb}$ core in southern Poland. Dalmatian Coast and Italy were under the influence of Mediterranean cyclone (1010 mb), which stayed for 36 hours over the Adriatic Sea. Only south-western Europe was under the influence of Azores High and Ridge (Fig.3.a). At $500 \mathrm{hPa}$ level, over Southeastern Europe was a ridge of 576 damgp and $-10^{\circ} \mathrm{C}$ temperature (Fig.3.b).

Atmospheric fronts related with those cyclonic nuclei have influenced northern, central and southern Europe. On the back side of the cyclonic core positioned in southern Poland, cold maritime polar air from the North and Baltic Sea was advected, thus the deepening of the $1000 \mathrm{mb}$ cyclonic core (that reached north-western Romania on June 9, 00 UTC) by the contact with the moist warmer tropical air from south-east. Frontal systems associated to this depression had a 4 to $6{ }^{\circ} \mathrm{C}$ thermal contrast, both at ground level and at $850 \mathrm{hPa}$ level At the ground 
level, air flow remained southwesternly and the cold front was located in the west and northwest of Romania Fig.4.a).

(a)

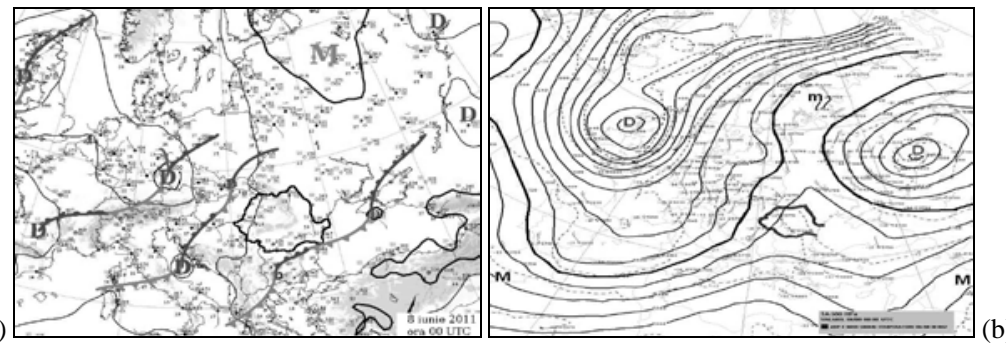

Fig. 3. a) Sea-level pressure and frontal systems analysis over Europe;

b) Geopotential and temperature at 500 hPa level; June 08,2011,00 UTC (National Administration of Meteorology, Archive maps)

In middle troposphere, at $500 \mathrm{hPa}$ level, Icelandic depression through extended to Southeastern Europe, because the withdrawing of thermal and geopotential ridge. Geopotential field structure did not have large variations during this time. Romania was situated on the south-eastern part of the Icelandic through (with a geopotential of 572 damgp and temperature of $-14^{\circ} \mathrm{C}$ ). Thus, the southwestern air movement facilitated moist maritime tropical air from the Adriatic Sea basin submission over the country. Eastward through movement increased southern air circulation on his upward part over mid-western Romania, amplifying cyclonic processes in lower troposphere (synoptic scale forcing - Fig..4 b)

a)
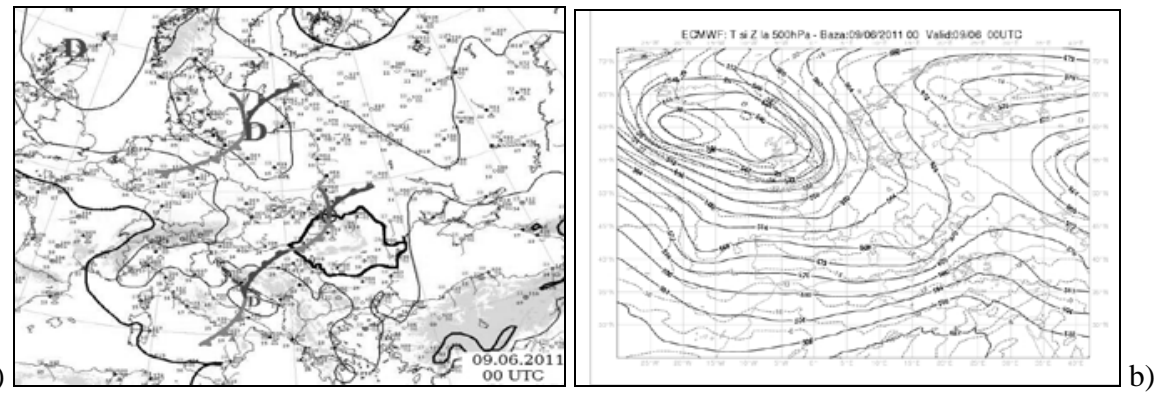

Fig. 4. (a) Sea- level pressure and Europe frontal analysis. (b) Geopotential and temperature at 500 hPa (ECMWF analysis) - June 9, 2011, 00 UTC (National Administration of Meteorology, Archive maps)

Between June 9, 06 UTC and June 10, 00 UTC, a large depressionary system affected northern, central and southeastern Europe, including Romania (with $1005 \mathrm{mb}$ sea-level pressure), the cyclonic core of $1000 \mathrm{mb}$ being positioned over southwestern Ukraine. The associated cold front crossed our country, reaching southern Transylvania on June 10, 00 UTC, while circulation on ground level became northwestern (Fig.5.a). In the altitude, at $500 \mathrm{hPa}$ level, due to the warm ridge withdrawal to the Black Sea, geopotential values decreased with 8 damgp. ECMWF model analysis of 10 June, 00 UTC identified a core of 564 damgp and a temperature of $-15{ }^{0} \mathrm{C}$ over southern Transylvania, correspondent to the cyclonic 
core on the ground (Fig. 5c). Thermal asymmetry of the cyclonic core was indicated by the westward tilted vertical axis. Air circulation at $500 \mathrm{hPa}$ level became northeastern, but warm air withdrawal at this level was slower than at 850 hPa level (whith a $12{ }^{\circ} \mathrm{C}$ isotherm) and on the ground, where cooling was of $5-6{ }^{\circ} \mathrm{C}$ and circulation was already northwest. This gap has favored the increase of the vertical thermal contrast and thus the increasing of convective energetic potentiall during the day of June 9 (Fig. 5b).
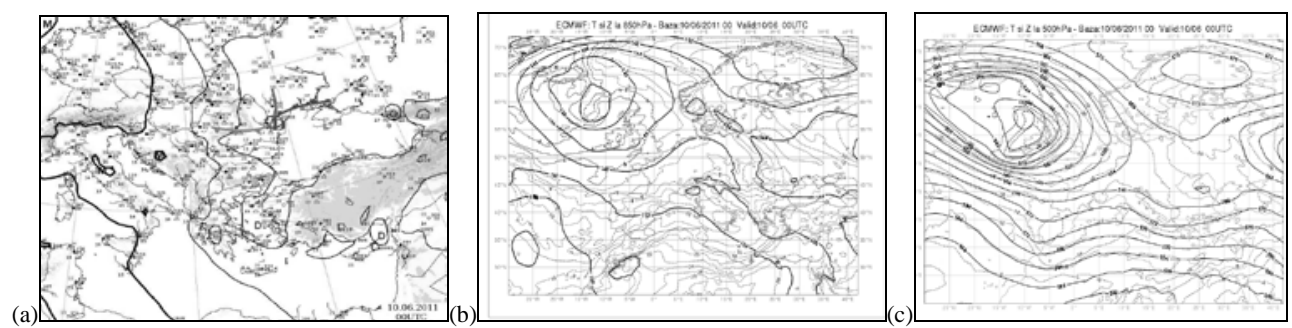

Fig.5 June 10,2011 at 00 UTC: a) Sea-level pressure and frontal analysis over Europe; b) ECMWF: 850 hPa geopotential and temperature; c) ECMWF: 500 hPa geopotential and temperature, (National Administration of Meteorology, Archive maps)

Between June 10 at 06 UTC and 11 at 06 UTC, the cyclonic core (of 1000 $\mathrm{mb}$ ) moved to east, so that on June 11 at 00 UTC it was situated in the northern Black Sea, while the associated cold front was located on southeastern Romania (Fig. 6a). In the middle troposphere, on $500 \mathrm{hPa}$ level, geopotential values increased slightly, with a ridge of 568 damgp in western Romania and a north circulation, according to ARPEGE model analysis from June 11 at 00 UTC. Over Romania, air circulation was from north throughout all the tropospheric column (Fig. 6b).

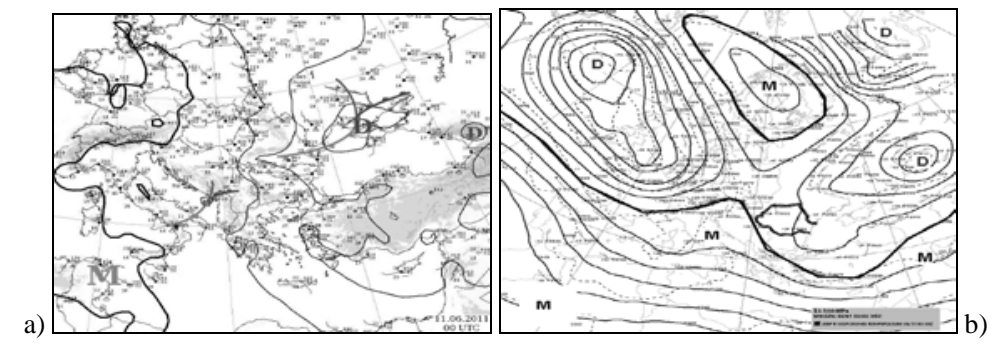

Fig .6. ARPEGE analysis for June 11 at 00 UTC: a) Europe ground-level pressure and fronts; b) Geopotential and temperature at 500 hPa level (National Administration of Meteorology, Archive maps)

\subsection{Satellite images}

The water vapor satellite image (MSG-WV $6.2 \mu \mathrm{m}$ ) from June 9 at 00 UTC (Fig.7a) shows: (1) - a clear sharp like angle structure in the west and southwest of the country, corresponding to the dry stratospheric air infiltration area; (2) - warm sector of the cyclonic core, visible because of high clouds water vapor content in white, spread over west, central and southwestern part of Romania; warm sector 
corresponds to the sea-level pressure ridge, indicating the warm air expansion over the entire column. On the RGB air mass satellite image from June 10, at 00 UTC (Fig.7b), black isolines indicate sea-level pressure field, with the cyclonic core positioned on the border with Moldova Republic; gray isolines indicate the $500 \mathrm{hPa}$ geopotential field, with a 564 damgp core (and -15 gr.C) and the air flow at $300 \mathrm{hPa}$ level. Stratospheric dry air intrusion in the southeastern Romania was responsible for lower troposphere cyclogenesis maintenance.

a)
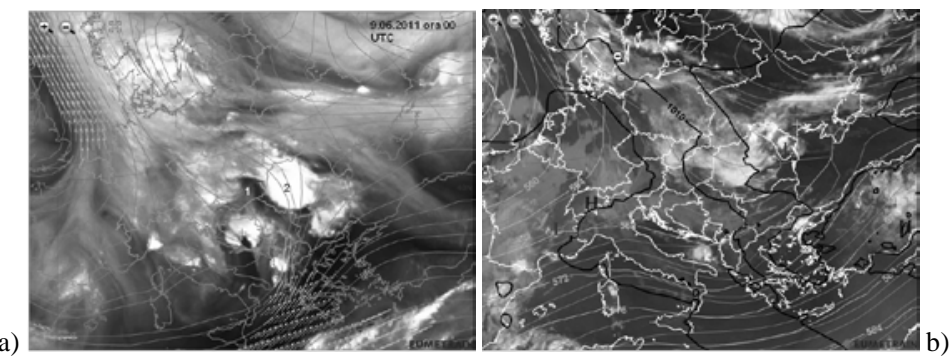

Fig. 7. a) MSG-WV6.2 from June 09, 2011 at 00 UTC; b) MSG-Air mass RGB from June 10, 2011 at 00 UTC; (National Administration of Meteorology, Archive maps)

\subsection{Mesoscale analysis: 2011, June 10 at 06 UTC - June 11 at 06 UTC}

For the mesoscale analysis of the period with the highest amount of precipitation registered at meteorological station Bâlea-Lac $(236.7 \mathrm{~mm}$ in 24 hours), numerical outputs of ALADIN limited area model was used. As regarding sea-level pressure, variations for every 1 milibar were analysed (Fig.8.a). On June 10, at 00 UTC, the sea-level air pressure core of $1003 \mathrm{mb}$ was positioned at the border with Moldova Republic, and on June 11 at 00 UTC was in the northern Black Sea, with $1000 \mathrm{mb}$ (Fig.8.b and c).
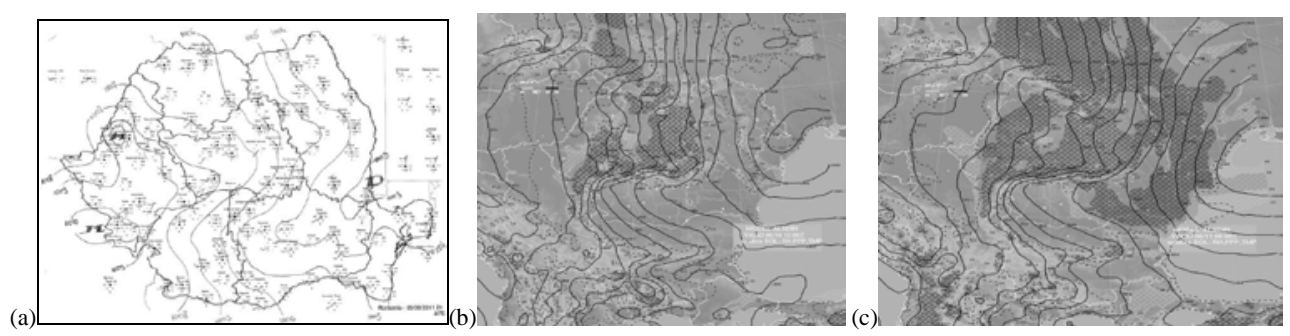

Fig. 8 - a) sea-level pressure analysis on June 10 at 00 UTC; b) ALADIN limited area model outputs for sea-level pressure, humidity and temperature, on June 10 at 12 UTC and (c) June 11 at 00 UTC, (National Administration of Meteorology, Archive maps)

On June 10 at 12 UTC, the cyclonic core situated in southwestern Ukraine has deepened to $999 \mathrm{mb}$, indicating the cyclogenesis intensification. Air circulation at ground level, in the northern half of the country was mainly from north. Sea-level pressure gradient was high, with values between 1004 and $1008 \mathrm{mb}$ over Transylvania (Fig.8.a), and continued to rise slightly for the next 12 hours. Analyzing the structure and distribution of isotherms on ground level for June 10 at 12 UTC 
(Fig.8.b), a large temperature gradient between the center and extra carpathian areas could be seen, as well as a 5-6 ${ }^{0} \mathrm{C}$ vertical thermic gradient between ground level and $1500 \mathrm{~m}$ altitude in Transylvania. On June 11 at 00 UTC (Fig.8.c), the cyclonic core was over the Black Sea, favoring warmer $\left(10{ }^{\circ} \mathrm{C}\right.$ warmer $)$ and more humid air advection from the Black Sea to Moldova, Muntenia and also Transylvania, where has caused a deep weather instability in contact with the cooler air.

Fig. 9 indicates that the structures of $850 \mathrm{hPa}$ geopotential, moisture and temperature over Romania remained quite similar on June 10, at 00 UTC (a), 12 UTC (b) and June 11, 00 UTC (c). The center of the cyclonic core left the Romanian territory, up to southern Ukraine, where filling phase core began, the cold occluded front still generating substantial rainfall in southern Transylvania.

(a)
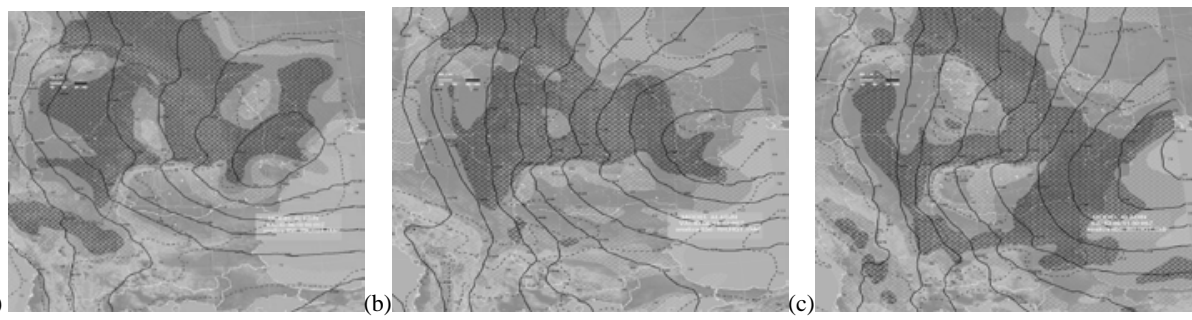

Fig. 9. ALADIN: analysis of geopotential, moisture and temperature on $850 \mathrm{hPa}$ level, on June 10 at 00 UTC (a), 12 UTC (b) and June 11, at 00 UTC (c), (National Administration of Meteorology, Archive maps)

On June 10, 00 UTC, at $500 \mathrm{hPa}$ level, a core of 565 damgp and $-14{ }^{\circ} \mathrm{C}$ could be identified on a large through, correspondent to sea-level pressure system. The westward inclined vertical axis (from the ground up to $500 \mathrm{hPa}$ ) indicate the existing thermal asymmetry in the evolution of cyclonic core over Romania at that time. While the geopotential values remained stationary (565 damgp), eastward altitude core movement (of 562 damgp, situated in northwestern Black Sea) determined a rapid 24 hours change of medium troposphere air circulation over Romania: initially eastern, north-eastern on June 10 at 12 UTC, then northern (Fig.10). For the studied intervall, the results from limited area ALADIN model, showed more than $90 \%$ moisture from the ground up in the middle troposphere (Fig.8-10).

(a)
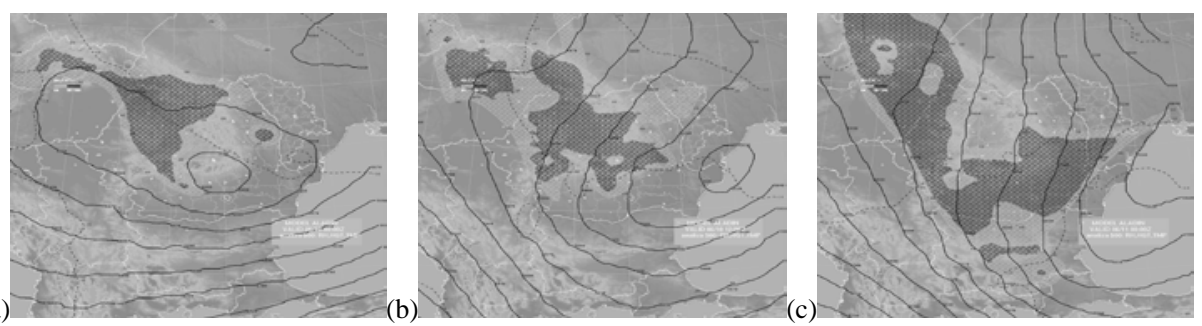

Fig. 11. ALADIN model - 500 hPa on June 10, 00 UTC, June 10, 12 UTC, June 11, 00 UTC (geopotential, humidity, temperature), (National Administration of Meteorology, Archive maps) 
To summarize, Figure 12 describes cyclonic core trajectory on the ground and at $500 \mathrm{hPa}$. On June 08, 2011 at $00 \mathrm{UTC}$, in the altitude, at $500 \mathrm{hPa}$ level, a 576 damgp slightly decreasing through was acting over western Romania. After 24 hours, the 500 hPa core of 564 damgp and $-14{ }^{\circ} \mathrm{C}$ was identified over the Făgăraş Mountains. Later, on June 11, 00 UTC, the ground cyclonic core had a corespondant on the altitude, at 850, 700 and 500 damgp - whose core reached the north of Black Sea (with 562 damgp and $-14{ }^{\circ} \mathrm{C}$ ), indicating its occlusion phase and thermal based homogenization.

(a)
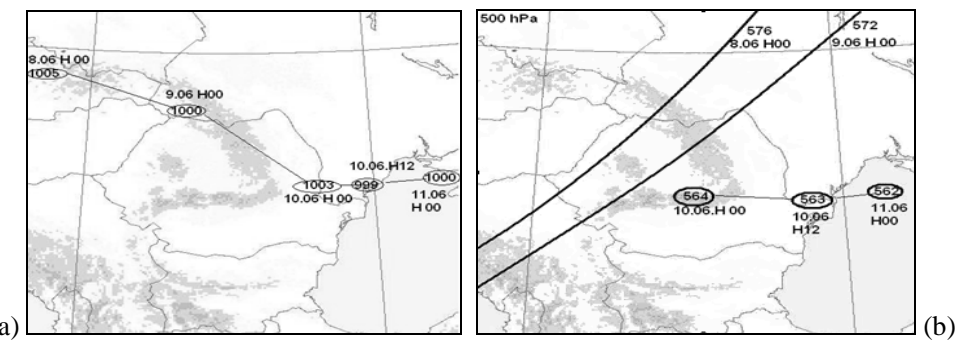

Fig. 12. Cyclonic core trajectory on ground level (a) and $500 \mathrm{hPa}$ level (b) between June 08,2011,00 UTC - June 11,2011,00 UTC

\section{CONCLUSIONS}

Severe weather episode from June 2011 was caused by the cyclonic core of Icelandic origin, that moved over half north-eastern Romania. Ground-pressure evolution was activated by all correspondent altitude structures. In the middle troposphere, wide Icelandic depression through, with a mesoscale identified cold core, caused cyclogenetic processes intensification by forcing from higher levels. Moisture advection, orographic forcing, slopes orientation and valleys position toward mesoscale air circulation had an important influence over the rainfall intensity over the northern slope of the Făgăraş Mountains.

\section{REFERENCES}

1. Ion-Bordei E, (2009), Rolul lanţului Alpino - Carpatic în evoluţia cicilonilor mediteraneeni - second edition, Printech Publishing House, Bucharest, 92-106

2. Bogdan O., Niculescu E., (1999), Riscurile climatice din România, Editura Saga Internaţional, Bucureşti ;

3. Donciu C., (1929), Contribuțiuni la climatologia Basarabiei, Regimul Precipitaţiunilor, Editura Naţională București, $69 \mathrm{p}$

4. Blaga C., Stăncescu M., (2009), Inundaţiile produse în urma precipitaţiilor din 11 si 12 iulie 2009 în zona montană si submontană a judeţului Sibiu, National Administration of Meteorology, internal study

5. Stăncescu M., Milian N., (2012), Heavy Precipitation in the Fagaras Mountains, 1-4 June 1988, Aerul şi Apa Componente ale Mediului, 2012,

6. National Administration of Meteorology, Archive maps, November 10, 2016

7. National Administration of Meteorology, Data base, November 11, 2016

8. SGA Sibiu, internal map

9. http://www.wetter3.de/Archiv/, accesed on November 09, 2016 